\title{
Trends in medicalisation of female genital mutilation/cutting: What do the data reveal?
}

Bettina Shell-Duncan

Carolyne Njue

Zhuzhi Moore

Follow this and additional works at: https://knowledgecommons.popcouncil.org/departments_sbsr-rh

Part of the Demography, Population, and Ecology Commons, Family, Life Course, and Society Commons, Gender and Sexuality Commons, and the International Public Health Commons How does access to this work benefit you? Let us know!

\section{Recommended Citation}

Shell-Duncan, Bettina, Carolyne Njue, and Zhuzhi Moore. 2018. "Trends in medicalisation of female genital mutilation/cutting: What do the data reveal?" Evidence to End FGM/C: Research to Help Women Thrive. New York: Population Council. 


\section{Evidence to End FGM/C}

Research to Help Girls and Women Thrive

\section{TRENDS IN MEDICALISATION OF FEMALE GENITAL MUTILATION/CUTTING: WHAT DO THE DATA REVEAL?}

October 2018 (Update) 


\section{TRENDS IN MEDICALISATION OF FEMALE GENITAL MUTILATION/CUTTING: WHAT DO THE DATA REVEAL? OCTOBER 2018 (UPDATE)}

BETTINA SHELL-DUNCAN UNIVERSITY OF WASHINGTON, SEATTLE, WASHINGTON, USA

CAROLYNE NJUE UNIVERSITY OF TECHNOLOGY, SYDNEY, NSW, AUSTRALIA

ZHUZHI MOORE INDEPENDENT CONSULTANT, VIENNA, VIRGINA, USA 
The Evidence to End FGM/C: Research to Help Girls and Women Thrive generates evidence to inform and influence investments, policies, and programmes for ending female genital mutilation/cutting in different contexts. Evidence to End FGM/C is led by the Population Council, Nairobi in partnership with the Africa Coordinating Centre for the Abandonment of Female Genital Mutilation/Cutting (ACCAF), Kenya; the Global Research and Advocacy Group (GRAG), Senegal; Population Council, Nigeria; Population Council, Egypt; Population Council, Ethiopia; MannionDaniels, Ltd. (MD); Population Reference Bureau (PRB); University of California, San Diego (Dr. Gerry Mackie); and University of Washington, Seattle (Prof. Bettina Shell-Duncan).

\section{POPULATION COUNCIL}

Ideas. Evidence. Impact.
The Population Council confronts critical health and development issues-from stopping the spread of HIV to improving reproductive health and ensuring that young people lead full and productive lives. Through biomedical, social science, and public health research in 50 countries, we work with our partners to deliver solutions that lead to more effective policies, programmes, and technologies that improve lives around the world. Established in 1952 and headquartered in New York, the Council is a nongovernmental, nonprofit organisation governed by an international board of trustees. www.popcouncil.org

The University of Washington is one of the world's preeminent public universities. Our impact on individuals, our region, and the world is profound - whether we are launching young people into a boundless future or confronting the grand challenges of our time through undaunted research and scholarship. We turn ideas into impact and transform lives and our world. www.washington.edu

Suggested Citation: Bettina Shell-Duncan, Carolyne Njue, and Zhuzhi Moore. 2018. "Trends in medicalisation of female genital mutilation/cutting: what do the data reveal? Updated October 2018." Evidence to End FGM/C: Research to Help Women Thrive. New York: Population Council.

(c) 2018. The Population Council, Inc.

Please address any inquiries about the Evidence to End FGM/C programme consortium to: Dr Jacinta Muteshi, Project Director, imuteshi@popcouncil.org

Funded by:

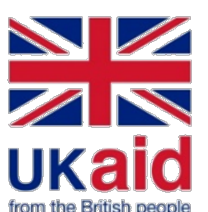

This document is an output from a programme funded by the UK Aid from the UK government for the benefit of developing countries. However, the views expressed and information contained in it are not necessarily those of, or endorsed by the UK government, which can accept no responsibility for such views or information or for any reliance placed on them. 


\section{Table of Contents}

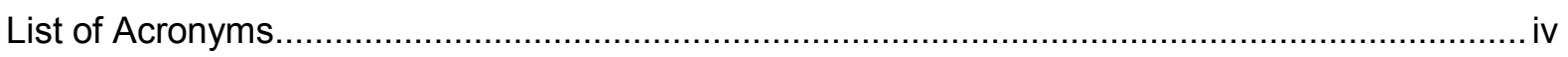

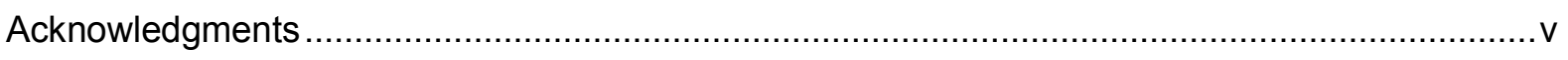

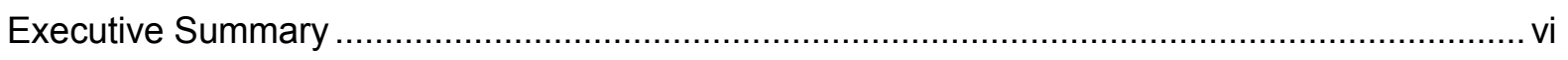

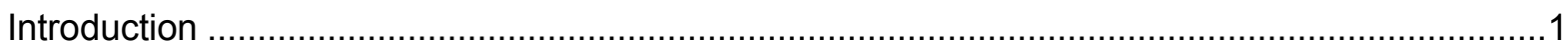

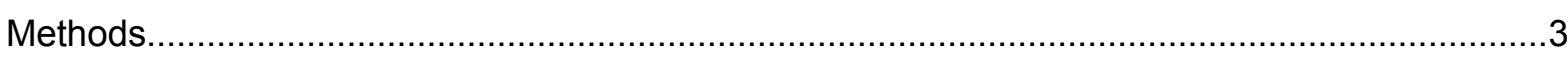

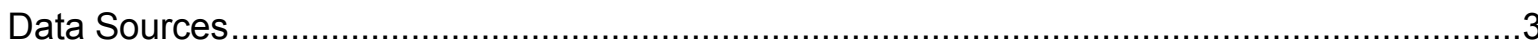

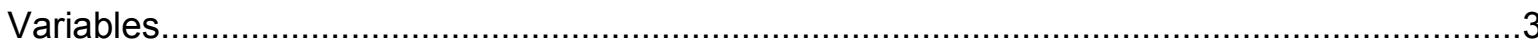

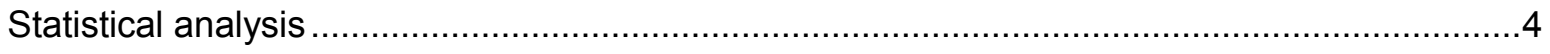

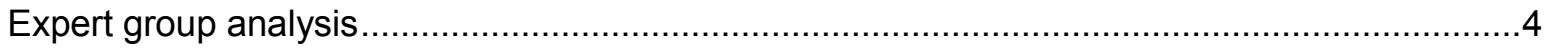

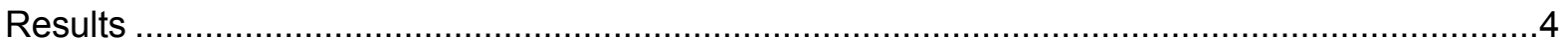

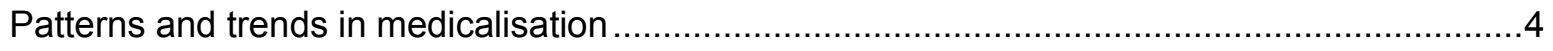

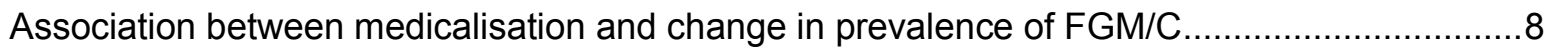

Association between medicalisation and support for the continuation of FGM/C ....................11

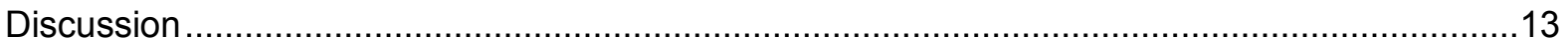

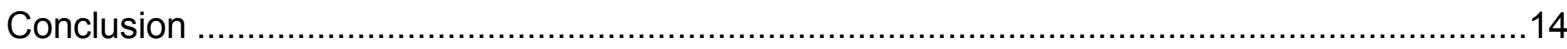

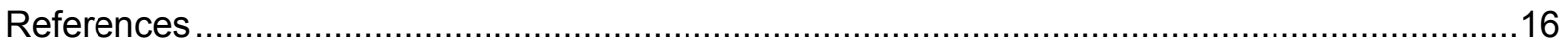




\section{List of Acronyms}

ACCAF

DHS

$\mathrm{FGM} / \mathrm{C}$

GRACe

HIS

MICS

PHS

SDGs

UNFPA

UNICEF

WHO
Africa Coordinating Centre for the Abandonment of FGM/C

Demographic and Health Survey

Female Genital Mutilation/Cutting

Gender and Reproductive Health and Rights Resources and Advocacy Center

Health Issues Survey

Multiple Indicator Cluster Survey

Population Health Survey

Sustainable Development Goals

United Nations Population Fund

United Nations Children's Fund

World Health Organization 


\section{Acknowledgments}

We are grateful to the UNICEF Khartoum office for providing data on the practitioners of FGM/C among daughters from the 2014 MICS survey conducted in Sudan. Corrine Mar from the Center for the Study of Demography and Ecology at University of Washington provided advice on presentation of the data and helped prepare several figures. We would like to thank Jacinta Muteshi and Otibho Obianwu for providing detailed review comments on earlier versions of this manuscript. We thank the panel of experts on medicalisation of FGM/C interviewed: Samuel Kimani from the Africa Coordinating Centre for the Abandonment of FGM/C (ACCAF), University of Nairobi, Kenya, Nafisa Bedri and Yussra Mohamed from the Gender and Reproductive Health and Rights Resources and Advocacy Center (GRACe) at Ahfad University for Women, Khartoum, Sudan, Salma Abou Hussein from Population Council in Cairo, Egypt, and Otibho Obianwu and Adetayo Adetunji from Population Council, Abuja, Nigeria. They shared possible interpretations of the data presented in this study based on their own research on medicalisation and offered an expert consensus on the conclusions reached at the end of this paper. Any error in this manuscript are, however, solely attributable to the authors.

Funding for this work was provided by UK Aid and the UK Government through the Department for International Development funded project, "Evidence to End FGM/C: Research to Help Girls and Women Thrive," coordinated by Population Council. Statistical support and grant administration through the Center for the Study of Demography and Ecology was supported by the Eunice Kennedy Shriver National Institute of Health and Human Development award number 5R24HD042828. 


\section{Executive Summary}

Medicalisation is defined by the World Health Organization as a situation in which female genital mutilation/cutting (FGM/C) "is practiced by any category of health-care provider, whether in a public or private clinic, at home, or elsewhere" (WHO, 2010: 2). Despite the emergence of international consensus that female genital mutilation/cutting (FGM/C) is a violation of human rights, a focus on medicalisation remains salient because of concerns that FGM/C is increasingly being performed by healthcare professionals and may be impeding progress toward abandonment of $F G M / C$. To investigate these claims, this study draws on nationally-representative survey data from 26 countries, and addresses the following three questions:

- What are the major patterns and trends in medicalisation?

- Is there an association between medicalisation and rates of change in prevalence of $\mathrm{FGM} / \mathrm{C}$ ?

- Is there an association between medicalisation and support for the continuation of the practice?

Results show that among women ages $15-49$ years, the majority $(79 \%)$ report having been cut by a traditional cutter, while an estimated 21 percent-totalling nearly 16 million girls and womenreport having been cut by a health care provider. Medicalised cutting is concentrated in three countries; 93 percent of women who report having undergone medicalised FGM/C live in Egypt, Sudan, and Nigeria. Elsewhere medicalised cutting is rare or restricted to geographic pockets. Data on practitioners of $\mathrm{FGM} / \mathrm{C}$ among daughters show that most cutting is carried out by traditional cutters in all countries except Egypt and Sudan, where daughter medicalisation rates are 78.4 percent and 77.5 percent, respectively. Mother-daughter comparisons reveal that in select countries, rates of medicalisation are increasing - most sharply in Egypt, where the medicalisation rate among daughters is nearly twice that of women. Successive survey data show that rising medicalisation rates are found in countries where $\mathrm{FGM} / \mathrm{C}$ rates are steady (Sudan) or dropping (Egypt and Kenya), but overall across countries, there is no correlation between medicalisation rates among daughters and rates of decline in FGM/C. National-level figures on medicalised cutting of daughters are not correlated with higher support for the continuation of FGM/C. Hence, it not clear that medicalisation undermines the ability to change attitudes against FGM/C. Nationallevel figures may mask important locally divergent factors influencing medicalisation and obscure sub-regional associations. Hence, further focused research is needed to explore this issue. 


\section{Introduction}

At a United Nations summit held in 2015, world leaders adopted a new set of goals and targets known as the Sustainable Development Goals (SDGs), outlining a development agenda for the next 15 years. SDG target 5.3 .2 calls for the elimination of all harmful traditional practices, including female genital mutilation/cutting (FGM/C), by the year 2030. FGM/C refers to a variety of practices involving the partial or total removal of the external female genitalia for non-therapeutic reasons. These range from nicking the tissue surrounding the clitoris to the complete removal of the external genitalia. WHO has classified different types of FGM/C as follows: Type I (clitoridectomy) involves removal of all or part of the clitoris and/or the prepuce; Type II (excision) involves removal of the clitoris and the labia minora with or without removal of the labia majora; Type III (infibulation) involves removal of all of the external genitalia, and appositioning the labia to form a seal, leaving a pinhole opening for the passage of urine and blood; and Type IV, all unclassified forms, including nicking, pricking, and scraping the skin covering or near the clitoris, but no removal of tissue (WHO, 2008). FGM/C occurs in countries extending from West to East Africa, through the Horn of Africa, and in parts of the Middle East and Southeast Asia. Surveys conducted across parts of Africa, the Middle East, and Southeast Asia document FGM/C prevalence rates ranging from 1\% (Uganda, Cameroon) to more than 95\% (Guinea and Somalia) (Shell-Duncan, Naik, \& Feldman-Jacobs, 2016; UNICEF, 2016). Although survey data are lacking, FGM/C has been described in countries including Colombia, Iran, India, Malaysia, Oman, Pakistan, Russia, and Thailand, as well as in migrant communities throughout the world originating from countries where $\mathrm{FGM} / \mathrm{C}$ is practised (BBC, 2016; Merli, 2012; UNICEF, 1998UNICEF, 2016). It has been estimated that worldwide, more than 200 million girls and women have undergone some form of FGM/C (UNICEF, 2016), and more than 3 million girls are estimated to be at risk of being cut each year. A growing body of research has documented that most forms of FGM/C can cause not only immediate health complications such as excessive bleeding and infection, but also long-lasting genito-urinary, obstetrical, and psychological problems (Berg, Denison, \& Fretheim, 2010; Berg, Underland, Odgaard-Jensen, Fretheim, \& Vist, 2014; WHO, 2006).

Global efforts to end FGM/C have intensified over the last four decades through combined efforts of international and non-governmental organisations, governments, religious and civil society groups. A wide range of intervention strategies have been implemented with the goal of accelerating abandonment of FGM/C. Initially, the most common approaches used information and education campaigns that sought to educate people about the adverse health outcomes associated with FGM/C. It was assumed that as people became increasingly aware of negative health risks, they would weigh this against the perceived positive aspects, and become motivated to abandon the practice (Muteshi \& Sass, 2005). Increasingly health education campaigns were complemented by more comprehensive strategies such as intergenerational dialogue programmes that facilitate conversation and critical assessment of $\mathrm{FGM} / \mathrm{C}$ among members of practising communities (Muteshi \& Sass, 2005), holistic community education programmes that culminate in public declarations to abandon FGM/C (WHO, 1999), and alternative rites of passage programmes that encourage upholding ceremonial aspects of girls' initiation but eliminating the cutting aspect (Chege, Askew, \& Liku, 2001; Hernlund, 2000). Most, to some extent, include education on adverse medical risks.

There has been speculation that a focus on health consequences of FGM/C may have inadvertently led to medicalisation of the practice (Carr, 1997; WHO, 2010). An early comparative overview of data on practitioners of FGM/C from Demographic and Health Survey (DHS) data drew attention to the "problem" that in certain settings FGM/C was being increasingly performed by health care providers (Carr, 1997). It also characterised declines in FGM/C prevalence as "limited 
and slow," with the practice still supported by large segments of the population (Carr, 1997). This has led to ongoing speculation that messaging on health risks motivated medicalisation more so than abandonment, thereby impeding progress toward abandonment (Carr, 1997; WHO, 2010). However, divergent views exist, with debates being centred on the question of whether medicalisation can be a viable harm reduction strategy that can serve as a step toward abandonment, or whether it legitimises the practice and promotes its perpetuation. During these ongoing debates, claims about trends in medicalisation and its effect on the continuation of FGM/C are based on limited empirical data.

Advocates of harm reduction have argued that a shift toward medicalised cutting can represent a transitional step toward abandonment (Obiora, 1997). This shift may reflect an openness to reassessing the way in which $\mathrm{FGM} / \mathrm{C}$ is performed, including the possibility of not performing it at all (Dawson, Homer, Turkmani, Black, \& Varol, 2015; Gele, Bo, \& Sundby, 2013; Modrek \& Sieverding, 2016). A study analysing the 2008 Egypt DHS data found that households were less likely to opt for FGM/C when medicalisation was more common among their daughter's peers; the authors suggested that medicalisation may be associated with changing norms surrounding FGM/C, opening possibilities for abandonment (Naguib, 2012). It is this logic that belies some, but not all, of the policies and measures that have been instituted to minimise harm from FGM/C. In countries such as Sudan and Somalia, trainings on FGM/C have been incorporated into the training curriculum for health care professionals, with the goal of promoting safer and less severe forms of cutting (Boddy, 2007; Gele et al., 2013; Gruenbaum, 1982; Kaphle, 2000; Valderrama, 2002). For a period, policies of the ministries of health in Egypt and Indonesia issued directives for FGM/C to be performed by health professionals (IRIN_News, September 1, 2011; Reefat, 2009). In parallel, beginning in the 1990's, as host countries received an increased number of immigrants from countries where $\mathrm{FGM} / \mathrm{C}$ is practised, several proposals were drafted to offer hospital-based nicking in lieu of more severe forms of cutting (Abdulcadir, Margairaz, Boulvain, \& Irion, 2011; Coleman, 1998; Obiora, 1997). Each of these proposals were met with sharp criticism and have not been implemented.

Opposition to medicalisation is also now endorsed by professional medical organisations around the world, including the International Federation of Gynecology and Obstetrics, which passed a resolution in 1994 opposing the performance of FGM/C under any circumstances, in health establishments or by health professionals (WHO, 2008). On December 20, 2012, the United Nations General Assembly passed a Resolution on Intensifying Global Efforts for the Elimination of Female Genital Mutilation [A/RC.3/67/L.21/Rev.1]. Its adoption reflects agreement that FGM/C constitutes a violation of human rights, and that all countries should take action to end the practice "committed within or outside a medical institution, and to take all necessary measures including enacting and enforcing legislation to prohibit FGM/C and protect women and girls from this form of violence, and to end impunity" [A/RC.3/67/L.21/Rev.1]. Currently 27 countries in Africa and the Middle East where FGM/C is practised have banned it by law or constitutional decree (ShellDuncan et al., 2016), and in at least six of these countries (Burkina Faso, Cote d'lvoire, Egypt, Eritrea, Mauritania, and Senegal), the criminal code specifies an elevated penalty (prison and/or fine) specifically for health care providers who perform FGM/C, in addition to the possibility of suspending their licenses (Shell-Duncan, Wander, Hernlund, \& Moreau, 2013).

Despite this emerging consensus, medicalised cutting is still occurring. Rates of medicalisation are purportedly continuing to climb despite mounting criticism, scrutiny, and legal regulation (Kimani \& Shell-Duncan, 2018; WHO, 2010). Medical ethicists have argued that the unacceptably slow progress toward abandonment justifies the endorsement of "de minimis" forms of FGM/C that do not carry long-term medical risks (Arora \& Jacobs, 2016). And soon courts of law will be asked to adjudicate on two landmark medicalisation cases. An upcoming case in the U.S. will decide whether medical practitioners who performed genital scraping on girls have violated a federal ban 
on FGM/C (Belluck, 2017). While in Kenya a doctor has filed a claim that the ban on FGM/C among adult women is unconstitutional by denying women a right to culture, to make choices about their body, and have access to medical care should they elect to undergo this procedure (Bhalla, 2018). Against this background, concerns remain as to whether medicalisation may be legitimising the practice and impeding progress toward abandonment (Doucet, Pallito, \& Groleau, 2017; Kimani \& Shell-Duncan, 2018). In an effort to fill this gap, we examine data on medicalisation from nationallyrepresentative survey data from 26 countries to make evidence-based inferences regarding some key debates surrounding the effects of medicalisation. First, we explore the patterns and trends in medicalisation. Second, to investigate the claim that medicalised cutting may slow rates of abandonment of $\mathrm{FGM} / \mathrm{C}$, we examine association between medicalisation and rates of change in prevalence of $\mathrm{FGM} / \mathrm{C}$, and the association between rates of medicalisation and level of support for the continuation of FGM/C.

\section{Methods}

\section{Data Sources}

Data on medicalisation of $\mathrm{FGM} / \mathrm{C}$ are available from nationally-representative data from 26 countries in Africa and the Middle East. Reliable nationally-representative data have been generated through several major household surveys: the DHS, the Multiple Indicator Cluster Surveys (MICS), the Egypt Health Issues Survey (HIS), and the Eritrea Population Health Survey (PHS). Each survey asks a sample of women of reproductive age (15-49 years) about their own FGM/C status, as well as the person who performed the cutting for those who have undergone FGM/C. Women with at least one living daughter are asked the same questions about at least one daughter, usually the most recently cut daughter or, in recent MICS and DHS surveys, all daughters between ages 0-14 years. The survey also asks women their opinion as to whether the practise of FGM/C should continue. Data were drawn from the final reports prepared for each survey. Where data were not available in final reports, they were obtained from the publicly available data sets.

\section{Variables}

Women's self-reported data on FGM/C come from the surveys described above. For each survey a random sample of women aged between 15 and 49 years was drawn using a two-stage cluster sampling procedure. Data on daughters were reported by their mothers. Data on support for continuation of $\mathrm{FGM} / \mathrm{C}$ was obtained from women who positively replied to a question about having ever heard of FGM/C. Most surveys posed the question as "Do you think this practice should continue? Or should it be discontinued?" This was followed by pre-coded responses: continued, discontinued, and it depends/not sure (UNFPA-UNICEF, 2013). The number of women who indicated they think FGM/C should continue was used to compute the percent of women who favour continuation of the practice. Questions about practitioners of FGM/C on women or on their daughters vary in form across surveys, and survey reports compiled categories in different forms. In many instances data on health personnel are divided as doctor and nurse/midwife/other health worker. Data on traditional circumcisers are often categorised as traditional practitioner and 'other traditional practitioner'. Some surveys have unique categories; for instance, the Egypt survey asks about the three categories (daya, barber, and ghagarie) that are found only in the Egypt female genital cutting module. Data from The Gambia and Yemen are reported in only two categories: health personnel and traditional practitioners. To allow comparisons across countries, we grouped practitioners into the two larger categories: traditional practitioners and health personnel. In the Cameroon survey (DHS 2004), data on type of practitioner of FGM/C were collected for women, but not daughters. 


\section{Statistical analysis}

The data reported throughout this report are weighted based on sampling design. Descriptive statistics to facilitate comparisons across countries and to discern patterns and trends are presented as frequencies and percentages. The outcome variables of interest are national prevalence of $\mathrm{FGM} / \mathrm{C}$, rates of medicalisation (defined as the percent of girls and women with FGM/C who report cutting performed by a health professional), percent of women who support the continuation of $\mathrm{FGM} / \mathrm{C}$, and type of health personnel who performed cutting (doctor versus nurse midwife or other health professional). For countries with consecutive surveys with comparable data on medicalisation and prevalence of FGM/C (Benin, Burkina Faso, Chad, Cote d'Ivoire, Egypt, Eritrea, Kenya, Mali, Niger, Nigeria, Senegal, Sudan, Togo, and the United Republic of Tanzania), trends across time were plotted and described. The U.S. Census Bureau's International Data Base (U.S. Census Bureau) was used to obtain midyear population estimates by five-year age cohorts by country for the year in which the survey data were collected. To estimate the total number of women aged between 15 and 49 years who are cut in any one of the countries, we tally the total number of women in this age range in the year that the most recent survey was conducted and multiply the number by the prevalence of $\mathrm{FGM} / \mathrm{C}$ among women aged 15-49 years (based on selfreported FGM/C status). The total number of women cut by health practitioners was estimated by multiplying the total number of women cut by the medicalisation rate. Following the methods of UNICEF (2013) we also use prevalence figures on age-specific cohorts to determine trends in change in $\mathrm{FGM} / \mathrm{C}$ prevalence. Specifically, we compare the prevalence of $\mathrm{FGM} / \mathrm{C}$ in the oldest age cohort (45-49 years) to the prevalence in the youngest age cohort (15-19 years). The percent change between the oldest and youngest age cohorts is used to compute the rate of decline in FGM/C. The Pearson correlation coefficient was computed between rates of medicalisation among daughters and two different measures: 1) percent of change in the prevalence of FGM/C between the eldest and youngest cohort, and 2) proportion of women aged 15-49 years who support the continuation of $\mathrm{FGM} / \mathrm{C}$.

\section{Expert group analysis}

To maximise understanding of the data, the interpretation of results was done in consultation with a panel of experts on medicalisation of $\mathrm{FGM} / \mathrm{C}$ who are conducting focused studies on this topic in their own countries. The experts interviewed were Samuel Kimani from the Africa Coordinating Centre for the Abandonment of FGM/C (ACCAF), University of Nairobi, Kenya; Nafisa Bedri and Yussra Mohamed from Gender and Reproductive Health and Rights Resources and Advocacy Center (GRACe) and Ahfad University for Women, Khartoum, Sudan; Salma Abou Hussein from Population Council in Cairo, Egypt; and Otibho Obianwu and Adetayo Adetunji from Population Council, Abuja, Nigeria. They offered possible interpretations of the data presented in this study based on their own research on medicalisation and offered an expert consensus on the conclusions reached at the end of this paper. This took place during a meeting of partners involved in the Evidence to End FGM/C: Research to Help Girls and Women Thrive research consortium, held in Nairobi, Kenya in February and March 2018.

\section{Results}

\section{Patterns and trends in medicalisation}

Self-reported data on the prevalence of $\mathrm{FGM} / \mathrm{C}$ and person who performed cutting are reported in Table 1. The prevalence of FGM/C among women aged 15-49 ranges from as low as 1-2 percent (Cameroon and Niger) up to 97 percent (Guinea). Among women with $F G M / C$, rates of medicalisation among women aged 15-49 are highest in five countries: Sudan (67\%), Egypt (42\%), 
Guinea (15\%), Kenya (15\%), and Nigeria (13\%). Elsewhere, medicalised cutting is rare and restricted to geographically defined pockets.

Table 1. Prevalence of FGM/C, medicalisation and total number of women (age 15-49) cut by health professionals from the most recent survey available*

\begin{tabular}{|c|c|c|c|c|c|c|}
\hline Country & $\begin{array}{l}\text { Data } \\
\text { Source }\end{array}$ & $\begin{array}{l}\text { Prevalence } \\
\text { (\%) }\end{array}$ & $\begin{array}{c}\text { Medicalisati } \\
\text { on Among } \\
\text { Women Cut } \\
(\%)\end{array}$ & $\begin{array}{c}\text { Total } \\
\text { Number of } \\
\text { Women (15- } \\
49)\end{array}$ & $\begin{array}{c}\text { Total } \\
\text { Number of } \\
\text { Women Cut }\end{array}$ & $\begin{array}{l}\text { Total Cut by } \\
\text { Health } \\
\text { Professionals }\end{array}$ \\
\hline Benin & MICS 2014 & 9.2 & 0.9 & $2,367,594$ & 217,819 & 1,960 \\
\hline Burkina Faso & $\begin{array}{l}\text { MICS/DHS } \\
2010\end{array}$ & 75.8 & 0.2 & $3,688,866$ & $2,796,160$ & 5,592 \\
\hline Cameroon & DHS 2004 & 1.4 & 4.0 & $4,098,869$ & 57,384 & 2,295 \\
\hline CAR & MICS 2010 & 24.2 & 2.3 & $1,172,050$ & 283,636 & 6,524 \\
\hline Chad & $\begin{array}{l}\text { DHS 2014- } \\
15\end{array}$ & 38.4 & 0.9 & $2,785,163$ & $1,107,229$ & 9,626 \\
\hline Côte d'Ivoire & MICS 2016 & 36.7 & 1.0 & $6,117,646$ & $2,022,276$ & 22,452 \\
\hline Djibouti & MICS 2006 & 93.1 & 6.0 & 193,365 & 180,023 & 10,801 \\
\hline Egypt & HIS 2015 & 87.2 & 42.2 & $23,857,123$ & $21,534,578$ & $8,820,646$ \\
\hline Eritrea & PHS 2010 & 83.0 & 0.3 & $1,289,441$ & 869,559 & 3,211 \\
\hline Ethiopia & DHS 2016 & 65.2 & 1.0 & $24,091,527$ & $15,707,676$ & 157,077 \\
\hline Gambia & DHS 2013 & 74.9 & 0.3 & 486,629 & 364,485 & 1,093 \\
\hline Ghana & MICS 2011 & 3.8 & 1.2 & $6,041,140$ & 229,563 & 2,755 \\
\hline Guinea & DHS 2012 & 96.9 & 15.4 & $2,518,996$ & $2,440,907$ & 375,900 \\
\hline Guinea-Bissau & MICS 2014 & 44.9 & 0.6 & 419,549 & 189,846 & 1,130 \\
\hline Iraq & MICS 2011 & 8.1 & 6.3 & $7,623,574$ & 617,509 & 38,903 \\
\hline Kenya & DHS 2014 & 21.0 & 14.7 & $10,877,750$ & $2,284,328$ & 335,796 \\
\hline Mali & MICS 2015 & 82.7 & 2.3 & $3,807,075$ & $3,221,836$ & 72,414 \\
\hline Mauritania & MICS 2015 & 66.3 & 11.9 & 934,407 & 580,939 & 3,112 \\
\hline Niger & DHS 2012 & 2.0 & 0.0 & $3,423,589$ & 68,472 & 0 \\
\hline Nigeria & $\begin{array}{l}\text { MICS } \\
2016-17\end{array}$ & 18.4 & 12.7 & $42,889,199$ & $9,787,758$ & 939,102 \\
\hline Senegal & DHS 2016 & 22.7 & 0.5 & $3,625,663$ & 854,176 & 0 \\
\hline Sierra Leone & DHS 2013 & 89.6 & 1.8 & $1,391,263$ & $1,246,572$ & 13712 \\
\hline Sudan & MICS 2014 & 86.6 & 66.8 & $8,752,649$ & $7,579,794$ & $5,063,302$ \\
\hline Togo & $\begin{array}{l}\text { DHS 2013- } \\
14\end{array}$ & 4.7 & 0.5 & $1,755,425$ & 63,105 & 413 \\
\hline Tanzania & $\begin{array}{l}\text { DHS 2015- } \\
16\end{array}$ & 10.0 & 1.8 & $11,902,487$ & $1,482,789$ & 21,424 \\
\hline
\end{tabular}


Table 1. Prevalence of FGM/C, medicalisation and total number of women (age 15-49) cut by health professionals from the most recent survey available*

\begin{tabular}{|c|c|c|c|c|c|c|}
\hline Country & $\begin{array}{l}\text { Data } \\
\text { Source }\end{array}$ & $\begin{array}{c}\text { Prevalence } \\
(\%)\end{array}$ & $\begin{array}{c}\text { Medicalisati } \\
\text { on Among } \\
\text { Women Cut } \\
(\%)\end{array}$ & $\begin{array}{c}\text { Total } \\
\text { Number of } \\
\text { Women (15- } \\
49)\end{array}$ & $\begin{array}{c}\text { Total } \\
\text { Number of } \\
\text { Women Cut }\end{array}$ & $\begin{array}{l}\text { Total Cut by } \\
\text { Health } \\
\text { Professionals }\end{array}$ \\
\hline Yemen & DHS 2013 & 18.5 & 3.0 & $6,040,827$ & $1,117,553$ & 33,527 \\
\hline Total & & & 26.2 & & $74,326,742$ & $15,941,674$ \\
\hline
\end{tabular}

* To calculate the total number of women cut by health professionals, data on mid-year population size of women aged 15-49 years (in the year the survey was conducted) were obtained from the U.S. Census Bureau International Database.

CAR: Central African Republic

In the 26 countries for which we have data on medicalisation, most women with FGM/C $(79 \%)$ report being cut by a traditional practitioner; and 21 percent, totalling 15,941,674, were reportedly cut by a health care provider. Of women who report medicalised cutting, more than half $(55 \%)$ reside in Egypt alone. Ninety-three percent of women who were cut by a health professional live in just three countries: Egypt, Sudan, and Nigeria (Figure 1).

Figure 1. Geographic distribution of women aged 15-49 years with FGM/C who report having been cut by a medical professional

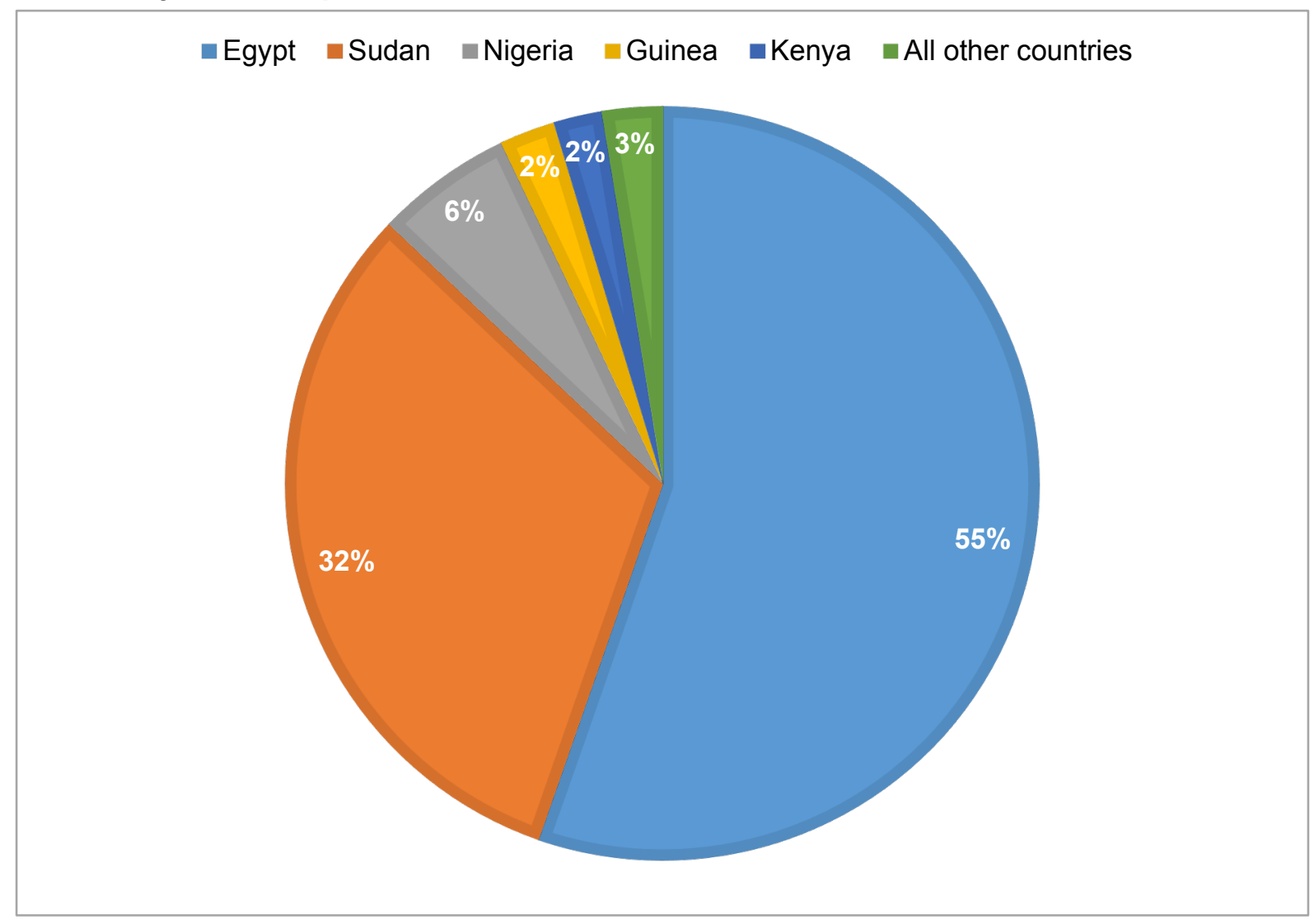

In 16 out of 24 countries, less than 10 percent of daughters with $\mathrm{FGM} / \mathrm{C}$ were cut by medical professionals (Figure 2). Overall, like in all women, the majority of FGM/C is most often performed on daughters by traditional practitioners. 
Figure 2. Type of practitioner of FGM/C on daughters

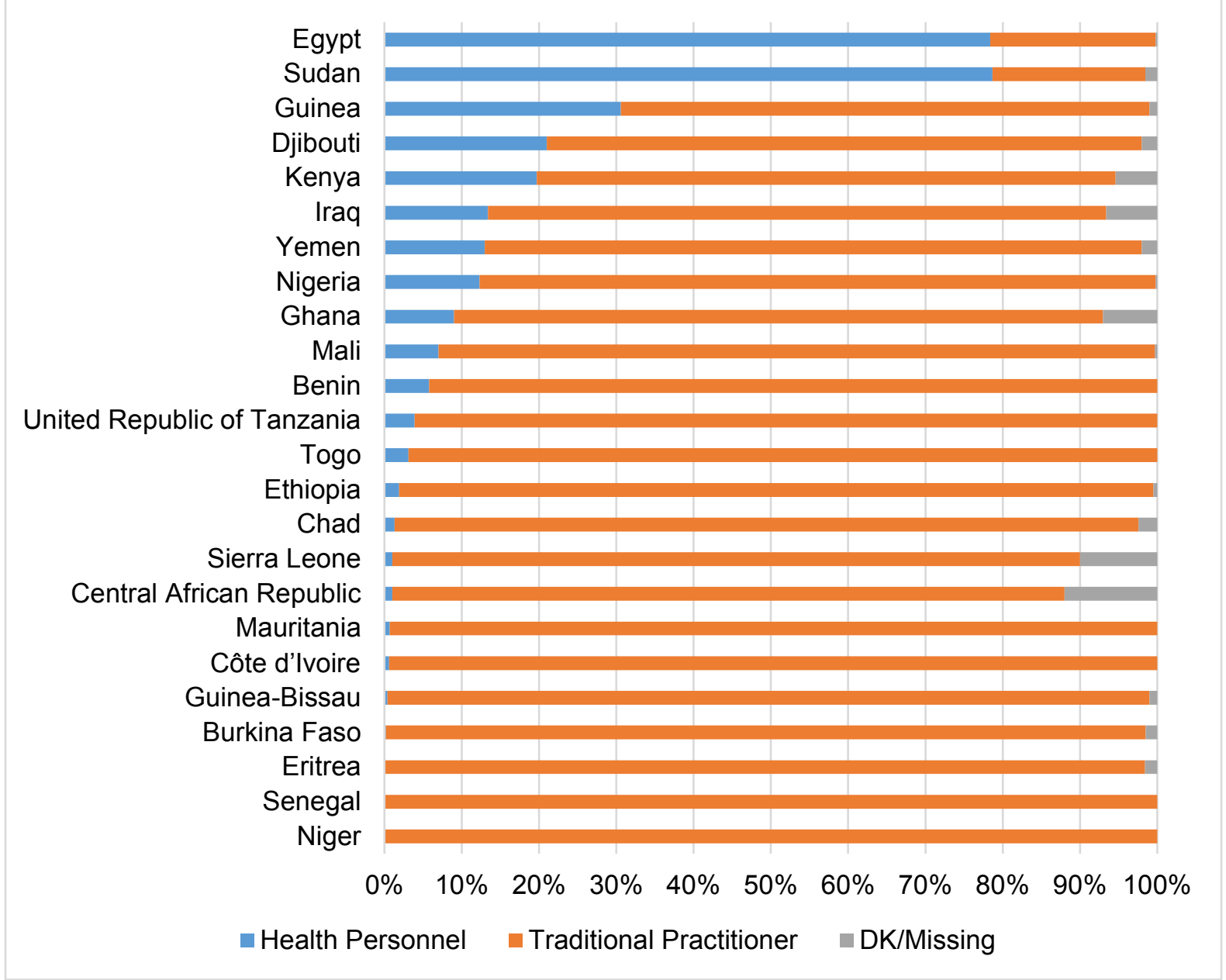

In eight countries, rates of medicalised cutting among daughters are 10 percent or higher (Figure 3). Comparing rates of medicalisation among mothers and daughters, rates are higher among daughters in each of these countries except Nigeria. The trend toward increased medicalisation in daughters, as compared to mothers, is most pronounced in Egypt, where medicalisation rates among daughters $(78 \%)$ are nearly twice those among women $(42 \%)$.

\section{Figure 3. Comparison of rates of medicalisation among mothers and daughters}

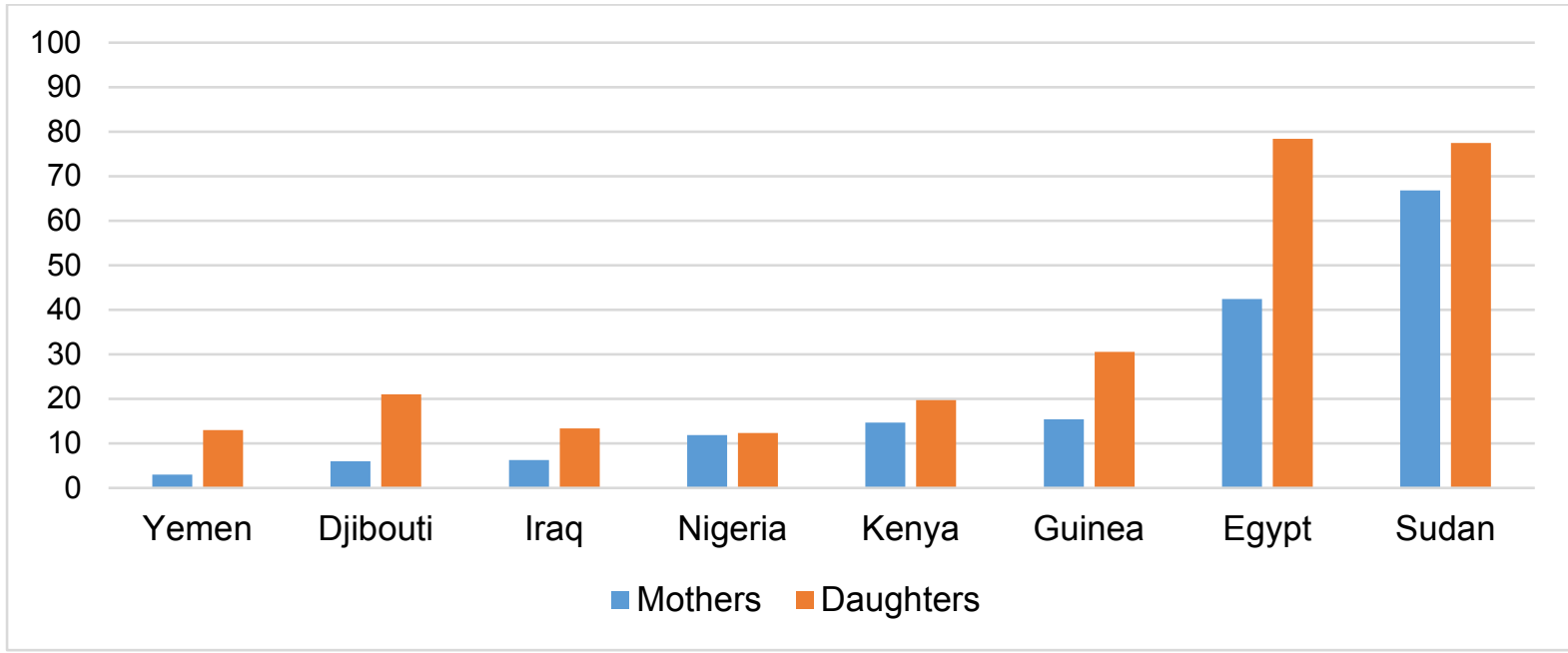


From the results, two categories of health professionals were identified to perform $\mathrm{FGM} / \mathrm{C}$ on daughters: 1) doctors, and 2) nurses, midwives, or other health professionals for the same countries (i.e., Sudan, Egypt, Guinea, Kenya, Nigeria, Djibouti, and Iraq) except Yemen, where only aggregated figures are reported (Figure 4). Egypt is unique in that doctors most commonly undertake FGM/C. In most countries where health care providers provide FGM/C on daughters, it is carried out by nurses, trained midwives, or other trained healthcare professionals.

Figure 4. Type of practitioner who performed FGM/C on daughters

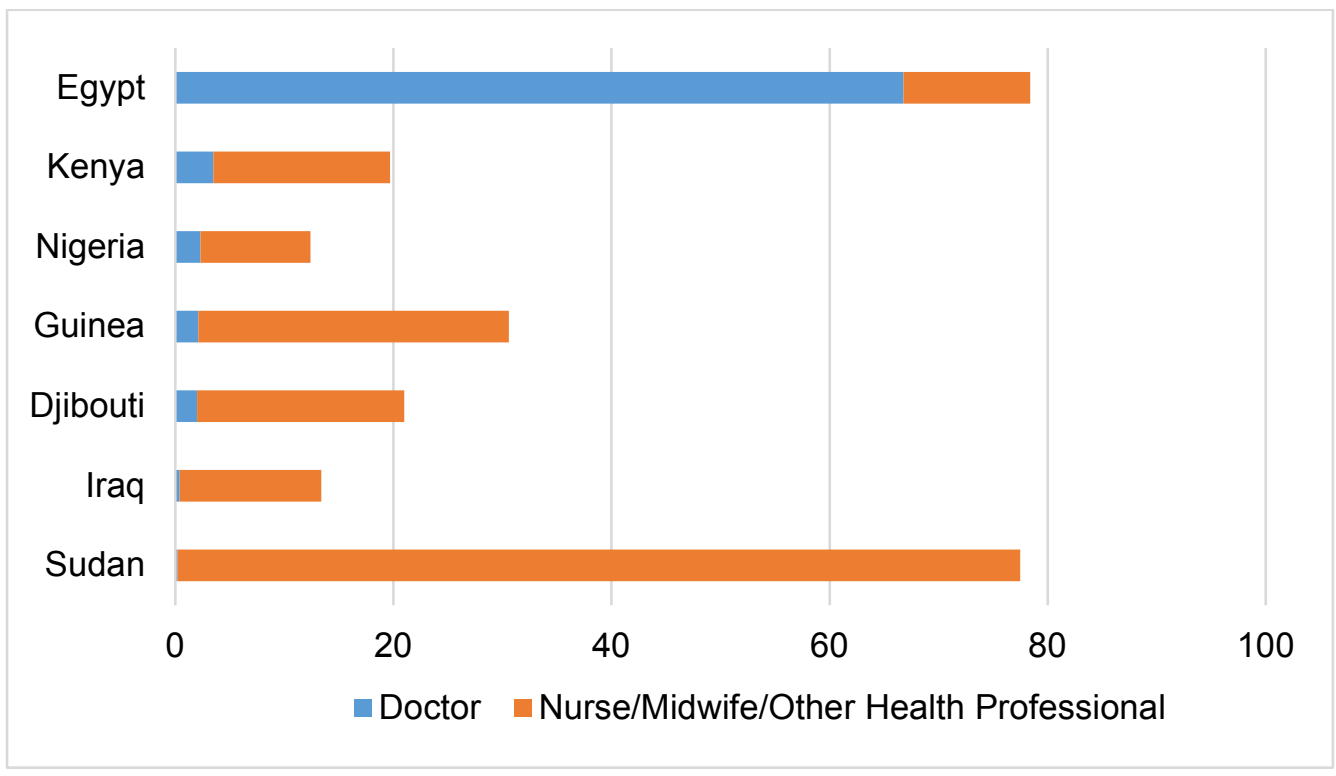

\section{Association between medicalisation and change in prevalence of FGM/C}

A key question is whether medicalisation counteracts efforts to eliminate $\mathrm{FGM} / \mathrm{C}$ and reduces rates of decline in FGM/C. This is a causal question for which counterfactual data do not exist; that is, we cannot answer the question, "would rates of decline have been higher had medicalisation not occurred?" With the data at hand, the change in prevalence of FGM/C is examined two ways: first by computing the percent change in prevalence between the youngest (15-19 years old) and oldest (40-49 year old) age cohorts of women, and second, by examining change in prevalence of FGM/C in women $15-49$ years across successive surveys.

Comparison of prevalence in these age cohorts are shown in Figure 5. The data show that the prevalence of $\mathrm{FGM} / \mathrm{C}$ is declining across age cohorts in all countries except The Gambia and Niger. 
Figure 5. Comparison of prevalence of FGM/C in the oldest (45-49) and youngest (15-19) age cohorts*

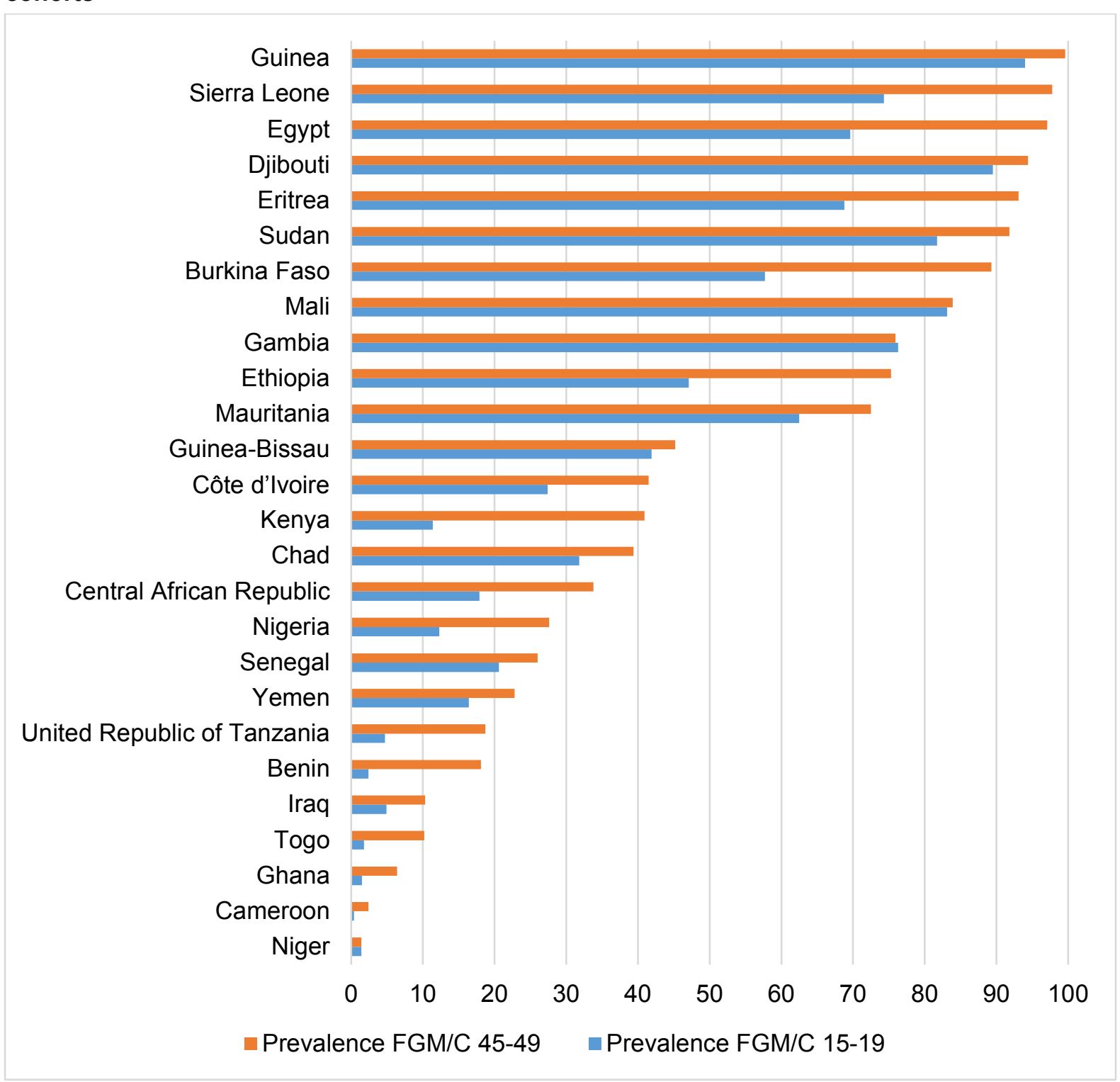

${ }^{*}$ For Ethiopia the oldest age cohort is $35-49$ years because of small $n$.

The rate of change across cohorts is computed as the percent change in prevelance between the oldest and youngest age cohorts. Figure 6 shows the association between the percent change in FGM/C prevalence in the oldest and youngest age cohorts and rates of medicalisation among daughters. The data show that the countries with the highest rates of medicalisation among daughters (Egypt, Sudan, Guinea, and Djibouti), have a low percent change in prevalence of $\mathrm{FGM} / \mathrm{C}$. At the same time, the country with the greatest decline in FGM/C across age cohorts, Kenya, has a 20 percent rate of medicalisation among daughters. Low rates of medicalisation are found in countries with widely ranging rates of change in $\mathrm{FGM} / \mathrm{C}$. Overall, there is not a significant correlation between the rate of decline in FGM/C and medicalisation ( $r=-0.25$, not significant). Thus, it is not clear that motivation to seek medicalised cutting is influences by rates of abandonment of FGM/C. 
Figure 6. Relationship between medicalisation rates among daughters and percent change in prevalence of FGM/C between youngest (15-19 years) and oldest (45-49 years) cohorts of women*

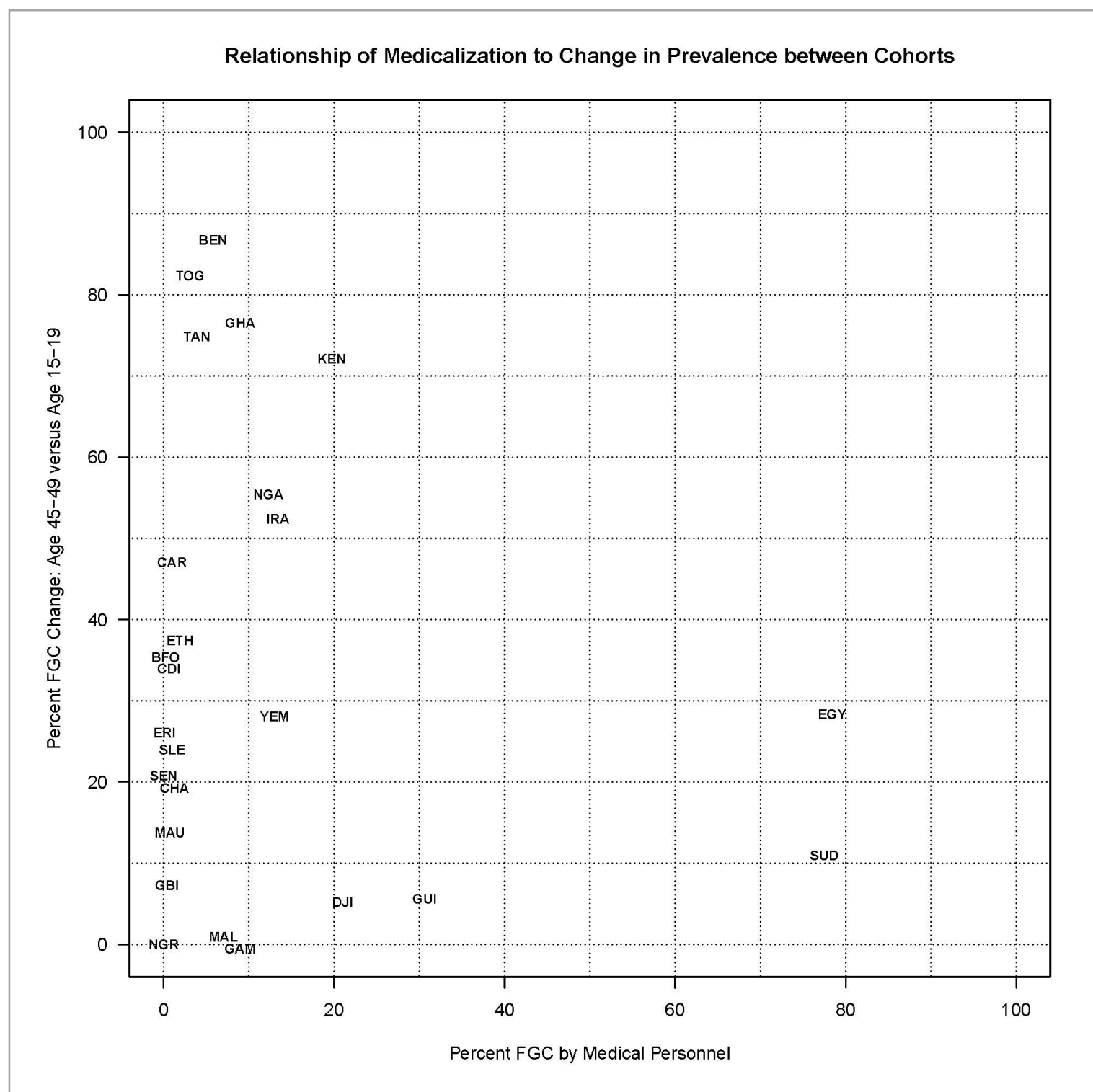

${ }^{*}$ Country codes: BEN - Benin; BFO - Burkina Faso; CAR - Central African Republlic; CHA - Chad; CDI - Côte d'Ivoire; DJI - Djibouti; EGY - Egypt; ERI - Eritrea; ETH - Ethiopia; GAM - Gambia; GHA - Ghana; GUI - Guinea; GBI - Guinea Bissau; IRA - Iraq; KEN - Kenya; MAL - Mali; MAU - Mauritania; NGR - Niger; NGA- Nigeria; SEN - Senegal; SLE - Sierra Leone; SUD - Sudan; TOG - Togo; TAN - United Republic of Tanzania; YEM - Yemen

Members of the expert panel on medicalisation suggested that national-level figures may mask regional variation in changes in $\mathrm{FGM} / \mathrm{C}$ prevalence and medicalisation with countries, and that local contexts and drivers of medicalisation vary substantially. For instance, in Nigeria, where Type I FGM/C is common, medicalisation is not being driven by parents' concerns about safety of the practice (it is already seen as a relatively benign practice) (Obianwu, personal communication). Instead, as women seek medicalised delivery services, $\mathrm{FGM} / \mathrm{C}$ is being offered as part of routine neonatal services (Obianwu, Adetunji, Dirisu, Ishaku, \& Adebajo, 2017). By contrast, in Egypt and Sudan, medicalisation has been linked to policies aimed at regulating harm (Bedri and Mohamed, personal communication, Hussein, personal communication), and may entrench the practise of FGM/C (Bedri, Sherfi, Elhadi, Rodwan, \& Elamin, In preparation; El-Gibaly \& Aziz, In preparation). 
Trends in prevalence of $\mathrm{FGM} / \mathrm{C}$ among women aged 15-49 years and medicalisation rates among daughters were examined through repeat survey data (available for 13 countries). Discernible changes in medicalisation are detectable in only three countries: Egypt, Kenya, and Sudan. In Sudan, consecutive surveys from 2010 and 2014 also revealed a sharp increase in daughters' medicalised cutting, rising from 55 percent to 78 percent. Over this period, the prevalence of FGM/C among women aged 15-49 years remained steady (88\% to 87\%). In Egypt between 1995 and 2015, rates of medicalised cutting among daughters rose sharply from 55 percent to 74 percent. During this period, the prevalence of FGM/C among women aged 15-49 years declined from 97 percent to 87 percent. Data from Kenya shows a mixed pattern of medicalisation and prevalence rates of $\mathrm{FGM} / \mathrm{C}$ across successive surveys. There was an increasing trend to have FGM/C performed by health care personnel (Figure 7), rising from 34 percent in 1998 to 41 percent in 2008-09, followed by a subsequent drop in 2014. This fluctuation in medicalisation rates has occurred simultaneously with a substantial decrease in the prevalence of FGM/C among women aged 15-49 years, dropping appreciably from 38 percent in 1998 to 21 percent in 2014. However, these data do not allow us to test causal associations nor whether the decline in FGM/C might have been even larger if health professionals were not performing FGM/C. Nonetheless, the results for Kenya indicate that medicalisation rose whilst FGM/C prevalence fell. The expert panel member from Kenya (Samuel Kimani) suggested that this pattern may be attributable to the fact that in Kenya, decreases in the prevalence vary dramatically along lines of ethnicity, and medicalisation is concentrated in communities that have been resistant to abandoning FGM/C (Kimani \& Kabiru, In preparation; Shell-Duncan, Gathara, \& Moore, 2017).

Figure 7. Trends in prevalence of FGM/C and medicalisation in Kenya

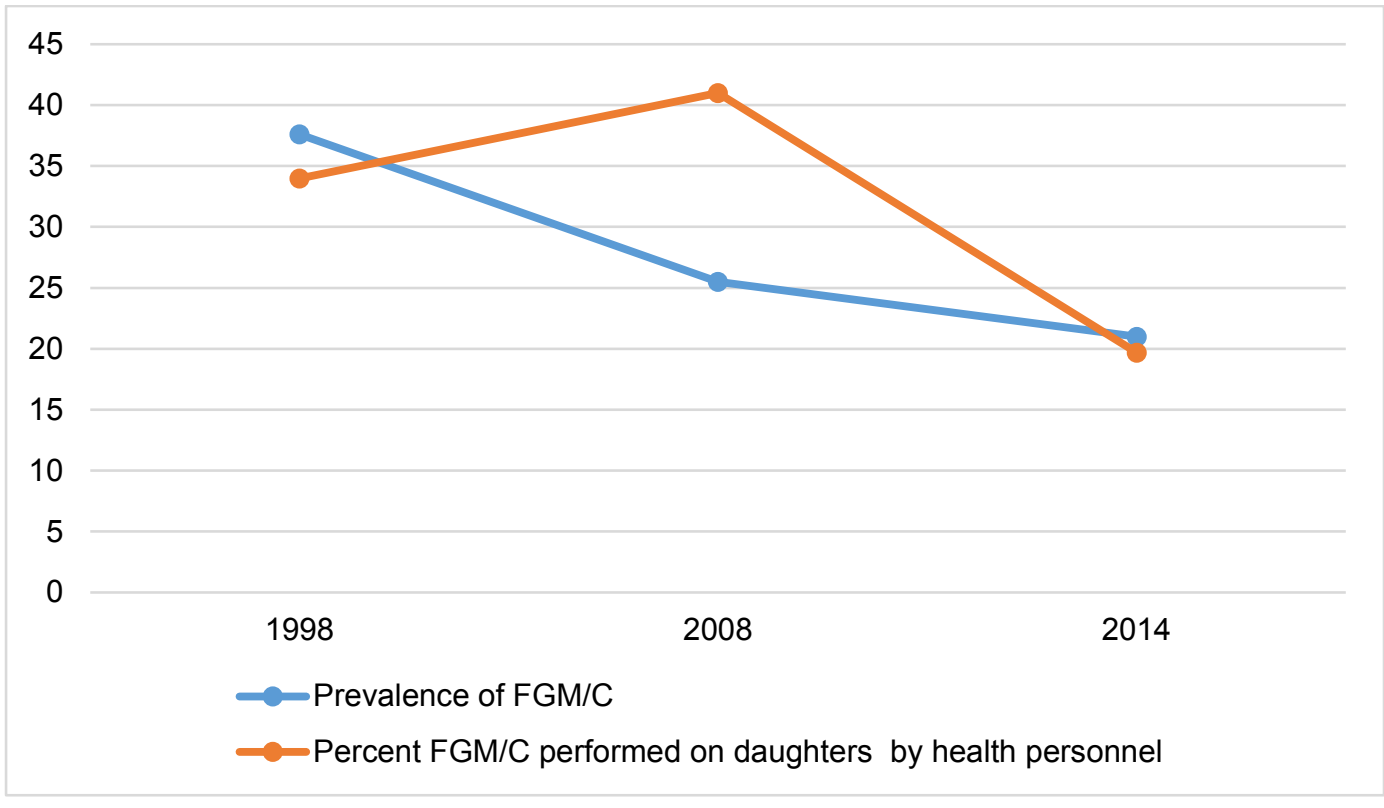

\section{Association between medicalisation and support for the continuation of FGM/C}

A related question is whether medicalisation influences support for the continuation of $F G M / C$. It has been posited that the availability of medicalised cutting may lead to continued support for FGM/C by creating the impression that it can be performed safely. Alternatively, mothers who opt for medicalised cutting for their daughters may be persuaded about the harmfulness of FGM/C and may be more likely to favour abandonment. 
Women's self-reported support for the continuation of FGM/C ranges from as high as 72 percent in Mali to as low as 1.5 percent in Ghana. Figure 8 plots the percentage of women who support the continuation of $\mathrm{FGM} / \mathrm{C}$ against rates of medicalisation among daughters. The results show that there is not a significant correlation between medicalisation and higher support for continuation of $\mathrm{FGM} / \mathrm{C}$ ( $\mathrm{r}=0.50$, not significant). This finding may also be linked to the fact that there is tremendous variation in factors motivating medicalisation and is not universally linked to concerns about health risks (expert panel and Kimani \& Kabiru, in preparation; Obianwu et al., 2017).

Figure 8. Relationship between medicalisation rates among daughters and the proportion of mothers who support the continuation of FGM/C*

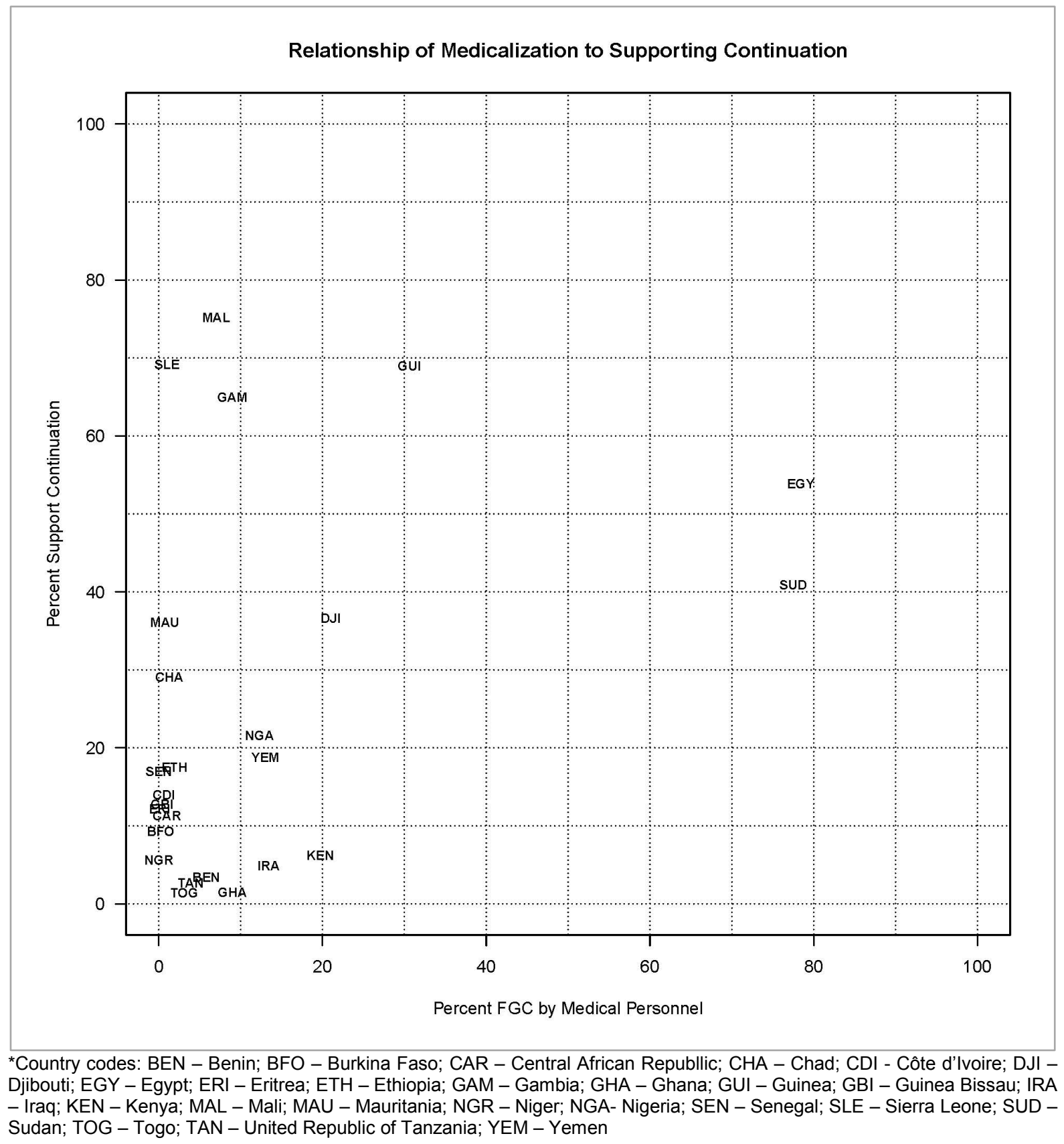




\section{Discussion}

This study draws on population-based survey results from 26 countries and the perspectives of members of the expert panel conducting focused studies on the medicalisation of FGM/C. Findings from the study reveals an estimated 21 percent of women with $\mathrm{FGM} / \mathrm{C}$ had the procedure performed by a health care provider (doctor, nurse, trained midwife, or other health professional), while the majority $(79 \%)$ reported being cut by a traditional circumciser. All told, nearly 16 million girls and women experienced medicalised cutting. Medicalised cutting is highly concentrated geographically. Of women who report having been cut by a health care provider, more than half (55\%) live in Egypt alone. Overall, 93 percent of women who reportedly experienced medicalised cutting live in Egypt, Sudan, and Nigeria. Elsewhere, medicalisation is rare or restricted to geographic pockets. Comparing medicalisation rates between survey respondents and their daughters, rates of medicalisation are increasing sharply in both Egypt and Sudan, but not in Nigeria.

Egypt appears to be unique in terms of being the only country in which medicalised cutting is carried out primarily by doctors, as opposed to nurses or other health workers. This trend is historically linked to health policies from the 1990's. In an effort to reduce the harm of what was viewed as an inevitable practice, the Ministry of Health issued a decree that lifted a 35-year ban on performing FGM/C in public hospitals in 1994 (El-Gibaly, Ibrahim, Mensch, \& Clark, 2002). The Ministry asked state hospitals to set aside one day a week for performing FGM/C "by trained physicians under hygienic conditions" (Reefat, 2009). This policy came under sharp criticism, was reversed to banning FGM/C in both state and private hospitals. A "loophole", however, allowed for "medically necessary circumcision," (Modrek \& Liu, 2013) and was not closed until 2007 by a Ministerial Decree prohibiting doctors, nursing staff, or others from performing FGM/C, whether in governmental or non-governmental hospitals. This decree was bolstered by the adoption of a 2008 law making FGM/C a crime punishable by imprisonment or fine. In January 2015, the first successful FGM-related prosecution took place, convicting a doctor of involuntary manslaughter for his role in the death of a 13-year-old girl and sentencing him to two years and three months in prison (Michaelson, 2016). In 2016, the law banning medical professionals from performing FGM/C in either state or privately-run clinics was amended to raise the maximum sentence from three to 15 years in prison (Sirgany, 2016).

In Sudan, where 67 percent of women with FGM/C report having undergone medicalised cutting, the procedure is in most instances performed by trained midwives. During the colonial era, government officials introduced measures intended to reduce the harm of infibulation by restricting the severity of cutting. Knowing that traditional birth attendants were the primary providers of FGM/C, midwifery schools established in Sudan in the 1920's taught a modified or "intermediate" (mitwasit) form of cutting that involved the same amount of cutting, but less stitching (Boddy, 2016). In 1946, a law was passed banning infibulation but allowing less severe forms of cutting. The law was ratified in 1956 when Sudan became independent but was dropped from the 1983 Penal Code. Although the Sudanese Medical Council has now banned FGM/C by any medical professional (Sharfi, Elmegboul, \& Abdella, 2013), there is no national law regulating FGM/C or medicalisation. Currently, WHO is conducting trials of interventions aimed at de-medicalisation of FGM/C in two states (Ahmed, 2017; Bukuluki, 2017). Such investigations are needed, as it is unclear how demedicalisation might influence strategies aimed at abandonment of FGM/C. One recent study in Egypt found that when a daughter's peers had undergone medicalised FGM/C, her own likelihood of being cut was in some instances reduced. The author suggests medicalisation may reflect shifting social norms that open change possibilities, including abandonment of FGM/C (Naguib, 2012). Whether this is also true in Kenya is unclear (Kimani \& Kabiru, In preparation). 
In Nigeria, girls and women who have experienced medicalised cutting are in most cases reportedly cut by nurses (Ashimi, Aliyu, Shittu, \& Amole, 2014; Obianwu et al., 2017). A recent qualitative study in Nigeria questions how often these providers are formally trained nurses or informally trained auxiliary nurses or midwives (Obianwu et al., 2017). It also showed that medicalisation is not driven primarily by harm reduction concerns, as it is widely considered to be a relatively benign procedure; instead it appears to be linked to an uptake in labour and deliver services in centres that offer FGM/C as part of routine neonatal care options (Obianwu et al., 2017).

Findings from the study also indicate that there is no significant correlation between rates of medicalisation among daughters and rates of decline in prevalence of FGM/C at the national level. Further multivariate analyses are needed to control for potentially confounding factors and account for subnational variation. Repeat survey data on medicalisation among daughters are available for 13 countries, and substantial changes in medicalisation are found in Egypt, Kenya, and Sudan. In Egypt and Kenya, medicalisation has occurred alongside declines in rates of FGM/C. At the same time, Sudan shows persistently high rates of $\mathrm{FGM} / \mathrm{C}$ alongside rising medicalisation rates. Whether medicalisation is hindering this decline is unclear but can be addressed in focused research.

Debates have also centred on whether medicalisation legitimises the practise of $F G M / C$ by creating an impression that the procedure may be performed safely, or whether parents who opt for medicalised cutting may be more open to change in FGM/C and less likely to support continuation of the practice (Dawson et al., 2015; Modrek \& Sieverding, 2016; Naguib, 2012). To investigate these claims, we examined the association between rates of medicalisation among daughters and mothers' stated support for the continuation of FGM/C and found no significant correlation.

There are a number of limitations in this study. We examined trends and correlations, which may be influenced by outliers, and as such further multivariate analyses are needed to control for potentially confounding factors, and to examine within-country patterns. Moreover, there are some concerns regarding the validity of the survey data used in this study. Self-reported data on FGM/C need to be treated with caution as inaccuracies may arise because of unwillingness to disclose having undergone $\mathrm{FGM} / \mathrm{C}$ due to the sensitivity of the topic or because of criminalisation of the practice (Askew, 2005; Shell-Duncan, 2017). Additionally, particularly when FGM/C is performed at an early age, women may be unaware of whether they have been cut or the extent of the cutting or may not accurately recall the circumstances surrounding the procedure. A number of studies have attempted to determine the reliability of self-reports of $\mathrm{FGM} / \mathrm{C}$ status (being cut or not) by verifying them through clinical examinations, and have reported variable rates of concordance (Adinma, 1997; Elmusharaf, Elhadi, \& Almroth, 2006; Klouman, Manongi, \& Klepp, 2005; Morison, Dirir, Elmi, Warsame, \& Dirir, 2004; Msuya et al., 2002; Snow, Slanger, Okonofu, Oronsaye, \& Wacker, 2002). The general consensus is that self-reports of being cut or not provide reasonably reliable estimates of FGM/C prevalence (Yoder \& Wang, 2013).

\section{Conclusion}

Among girls and women aged 15-49 who have undergone FGM/C, 21 percent have been cut by professional health care workers. For those working to deter or prevent medicalised cutting, it is important to recognise that it is concentrated in three countries namely Egypt, Sudan, and Nigeria. Mother-daughter comparisons indicate that medicalisation rates are increasing in several countries, most sharply in Egypt where rates have more than doubled. Further studies are needed to understand the rationale for selecting medicalised cutting, and whether or how medicalisation influences readiness to change $\mathrm{FGM} / \mathrm{C}$. The data do not show a significant association between medicalised FGM/C among daughters and rates of decline in prevalence of or support for the continuation of the practice. An expert panel on medicalisation suggested that it is likely that 
national-level figures mask important subnational variation in changes in FGM/C prevalence and medicalisation rates, as well as differences in factors driving medicalisation. Rising rates of medicalisation occur alongside both modest declines in FGM/C (in Egypt) and substantial declines in $\mathrm{FGM} / \mathrm{C}$ (Kenya). In Sudan, medicalisation rates rose while the prevalence of $\mathrm{FGM} / \mathrm{C}$ remained steady. Whether medicalisation is hindering abandonment of $F G M / C$ is unclear. The question remains as to whether this shift represents reluctance to stop an intractable practice or signifies openness to change that can be leveraged to promote abandonment. This is a pressing matter that influences actions needed to achieve the international community's recently adopted set of SDGs, including target 5.3.2 calling for the elimination of all harmful traditional practices such as FGM/C by 2030. Further focused research taking into account local contexts is needed to address this issue. 


\section{References}

Abdulcadir, J., Margairaz, C., Boulvain, M., \& Irion, O. (2011). Care of women with female genital mutilation/cutting. Swiss Medical Weekly, doi: 10.4414/smw.2011.13137.

Adinma, J. (1997). Current status of female circumcision among Nigerian Igbos. West African Journal of Medicine, 16, 227-231.

Ahmed, W. (2017). Quality improvement method to optimize female genital mutilation (FGM). Protocol for an in-service training package targeting community midwives in Northern and River Niles States, Sudan. Paper presented at meeting: "Female Genital Mutilation/Cutting: Sharing Data and Experiences. Improving Collaboration" Held in Geneva, Switzerland, March 13-14, 2017.

Arora, K. S., \& Jacobs, A. (2016). Female genital alteration: a compromise solution. Journal of Medical Ethics, 42(3), 148-154.

Ashimi, A., Aliyu, I., Shittu, M., \& Amole, T. (2014). A multicentre study on knowledge and attitude of nurses in northern Nigeria concerning female genital mutilation. The European Journal of Contraception and Reproductive Health Care, 19(2), 134-140.

Askew, I. (2005). Methodological issues in measuring the impact of interventions against female genital cutting. Culture, Health and Sexuality, 7(5), 463-477.

BBC. (2016). Russia furor over FGM in mainly Muslim Dagestan. BBC News online http://www.bbc.com/news/world-europe-37115746, August 18, 2016 date accessed: August 25, 2016.

Bedri, N., Sherfi, H., Elhadi, S., Rodwan, G., \& Elamin, W. (In preparation). Medicalisation of FGM/C in Sudan: health care provider and families' perspectives. Evidence to End FGM/C: Research to Help Girls and Women Thrive. New York: Population Council. http://www.popcouncil.org/EvidencetoEndFGM-C

Belluck, P. (2017). Michigan case adds new U.S. dimension to debate on genital mutilation. New York Times, June 10, 2017, https://www.nytimes.com/2017/06/10/health/genitalmutilation-muslim-dawoodi-bohra-michigan-case.html?mcubz=1, date accessed: August 1, 2017.

Berg, R., Denison, E., \& Fretheim, A. (2010). Psychological, social and sexual consequences of female genital mutilation/cutting (FGM/C): a systematic review on quantitative studies. Report from Kunnskapssenteret nr 13-2010. Oslo: Norwegian Knowledge Center.

Berg, R., Underland, V., Odgaard-Jensen, J., Fretheim, A., \& Vist, G. (2014). Effects of female genital cutting on physical health outcomes: a systematic review and meta-analysis. BMJ Open, doi: 10.1136/bmjopen-2014-006316.

Bhalla, N. (2018). Kenya doctor goes to court to legalize female genital mutilation. Reuters, January 19, 2018, https://af.reuters.com/article/commoditiesNews/idAFL3N1PE3NK, date accessed February 5, 2018.

Boddy, J. (2007). Civilizing Women: British Crusades in Colonial Sudan. Princeton, NJ: Princeton University Press.

Boddy, J. (2016). The normal and the aberrant in female genital cutting: shifting paradigms. HAU: Journal of Ethnographic Theory, 6(2), 41-69. 
Bukuluki, P. (2017). Drivers of FGM/C medicalization among community midwives in River Nile and Northern State, Sudan. Paper presented at meeting: "Female Genital Mutilation/Cutting: Sharing Data and Experiences. Improving Collaboration." Held in Geneva, Switzerland, March 13-14, 2017.

Carr, D. (1997). Female genital cutting: findings from the Demographic and Health Surveys Program. Calverton, MD: Macro International.

Chege, J. N., Askew, I., \& Liku, J. (2001). An assessment of the alternative rites approach for encouraging abandonment of female genital cutting in Kenya. New York, NY: Population Council.

Coleman, D. L. (1998). The Seattle compromise: multicultural sensitivity and Americanization. Duke Law Journal, 47, 717-783.

Dawson, A., Homer, C. S. E., Turkmani, S., Black, K., \& Varol, N. (2015). A systematic review of doctors' experiences and needs to support the care of women with female genital mutilation. International Journal of Gynecology and Obstetrics, 131, 35-40.

Doucet, M.-H., Pallito, C., \& Groleau, D. (2017). Understanding motivations of health-care providers in performing female genital mutilation: an integrative review. Reproductive Health, 14, 46-60. doi:10.1186/s12978-017-0306-5

El-Gibaly, O., \& Aziz, M. M. (In preparation). FGM/C in Egypt: perspectives of health care providers and mothers. Evidence to End FGM/C: Research to Help Girls and Women Thrive. New York: Population Council. http://www.popcouncil.org/EvidencetoEndFGM-C

El-Gibaly, O., Ibrahim, B., Mensch, B., \& Clark, W. (2002). The decline of female circumcision in Egypt: evidence and interpretation. Social Science and Medicine, 54(2), 205-220.

Elmusharaf, S., Elhadi, N., \& Almroth, L. (2006). Reliability of self-reported form of female genital mutilation and WHO classification: cross sectional study. BMJ, 333(7559), 124-128.

Gele, A. A., Bo, B. P., \& Sundby, J. (2013). Attitudes toward female circumcision among men and women in two districts in Somalia: is it time to rethink our eradication strategy in Somalia? Obstetrics and Gynecology International http://dx.doi.org//o.1155.2013/312734 doi:10.1155/2013/312734

Gruenbaum, E. (1982). The movement against clitoridectomy and infibulation in Sudan: public health policy and the women's movement. Medical Anthropology Newsletter, 13(2), 4-12.

Hernlund, Y. (2000). Cutting without ritual and ritual without cutting: Female "circumcision" and the re-ritualization of initiation in the Gambia. In B. Shell-Duncan \& Y. Hernlund (Eds.), Female "Circumcision" in Africa: Culture, Controversy, and Change (pp. 235-252). Boulder, CO: Lynne Rienner Publishers.

IRIN News. (September 1, 2011). FGM/C regulations mistaken as endorsement, experts fear. http://www.irinnews.org/report/93628/indonesia-fgmc-regulations-mistaken-endorsementexperts-fear, date accessed: December 1, 2016.

Kaphle, S. (2000). Report of Qualitative Research on the Communication Channels in use in Somalia. Somalia: UNICEF.

Kimani, S. \& Kabiru, C. W. (In preparation). Shifts in female genital mutilation/cutting in Kenya: perspectives of families and health care providers. Evidence to End FGM/C: Research to Help Girls and Women Thrive. New York: Population Council.

http://www.popcouncil.org/EvidencetoEndFGM-C 
Kimani, S., \& Shell-Duncan, B. (2018). Medicalized female genital mutilation/cutting: contentious practices and persistent debates. Current Sexual Health Reports https://doi.org/10.1007/s11930-018-0140-y.

Klouman, E., Manongi, R., \& Klepp, K. I. (2005). Self-reported and observed female genital cutting in rural Tanzania: associated demographic factors, HIV and sexually transmitted infections. Tropical Medicine and International Health, 10(1), 105-115.

Merli, C. (2012). Negotiating female genital cutting (sunat) in southern Thailand. In C. Raghavan \& J. Levine (Eds.), Self-Determination and Women's Rights in Muslim Societies (pp. 169187). Waltham, M.A.: Brandeis University Press.

Michaelson, R. (2016). First doctor convicted of FGM death in Egypt only spends three months in jail. The Guardian online ed., https://www.theguardian.com/world/2016/aug/02/egyptiandoctor-convicted-of-fgm-death-serves-three-months-in-jail accesses August 10, 2016.

Modrek, S., \& Liu, J. X. (2013). Exploration of pathways related to the decline in female circumcision in Egypt. BMC Public Health, 13, 921 http://www.biomedcentral.com/14712458/1413/1921.

Modrek, S., \& Sieverding, M. (2016). Mother, daughter, doctor: medical professionals and mothers' decision making about female genital cutting in Egypt. International Perspectives on Sexual and Reproductive Health, 42(2), 81-92.

Morison, L., Dirir, A., Elmi, S., Warsame, J., \& Dirir, S. (2004). How experiences and attitudes relating to female circumcision vary according to age on arrival in Britain: a study among young Somalis in London. Ethnicity and Health, 9(1), 75-100.

Msuya, S. E., Mbizvo, E., Hussain, A., Sundby, J., Sam, N. E., \& Stray-Pedersen, B. (2002). Female genital cutting in Kilimanjaro, Tanzania: changing attitudes? Tropical Medicine and International Health, 7(2), 159-165.

Muteshi, J., \& Sass, J. (2005). Female Genital mutilation in Africa: an analysis of current abandonment approaches. Retrieved from Nairobi, Kenya: Program for Appropriate Technology in Health.

Naguib, K. (2012). The effects of social interaction on female genital mutilation: evidence from Egypt. www.bu.edu/econ/files/2010/05/se_egypt.pdf, date accessed: January 6, 2015.

Obianwu, O., Adetunji, A., Dirisu, O., Ishaku, S., \& Adebajo, S. (2017). Understanding medicalization of female genital mutilation/cutting: a qualitative study of parents and health workers in Nigeria. Evidence to End FGM/C: Research to Help Girls and Women Thrive. New York: Population Council https://www.popcouncil.org/uploads/pdfs/2018RH_UnderstandingMedFGMC-Nigeria.pdf

Obiora, L. A. (1997). Bridges and barricades: rethinking polemics and intransigence in the campaign against female circumcision. Case Western Law Review, 47(2), 275-378.

Reefat, A. (2009). Medicalization of female genital cutting in Egypt. Eastern Mediterranean Health Journal, 15(6), 1379-1388.

Sharfi, A. R., Elmegboul, M. A., \& Abdella, A. A. (2013). The continuing challenge of female genital mutilation in Sudan. African Journal of Urology, 19(3), 136-140.

Shell-Duncan, B. (2017). Considerations on the use and interpretation of survey data on FGM/C. In E. Leye \& G. Coene (Eds.), Researching Female Genital Mutilation/Cutting. Proceedings of the 2nd International Academic Seminar of MAP-FGM Project (pp. 99106). Brussels: Vubpress Brussels University Press. 
Shell-Duncan, B., Gathara, D., \& Moore, Z. (2017). Female genital mutilation/cutting in Kenya: is change taking place? Descriptive statistics from four waves of Demographic and Health Surveys. New York: Population Council. Evidence to End FGM/C: Research to Help Girls and Women Thrive.

https://www.popcouncil.org/uploads/pdfs/2017RH_FGMCKenyaChange.pdf

Shell-Duncan, B., Naik, R., \& Feldman-Jacobs, C. (2016). A state-of-the-art synthesis on female genital mutilation/cutting: what do we know now? October 2016. New York: Population Council http://www.popcouncil.org/EvidencetoEndFGM-C.

Shell-Duncan, B., Wander, K., Hernlund, Y., \& Moreau, A. (2013). Legislating change?

Responses to criminalizing female genital mutilation/cutting in Senegal. Law and Society Review, 47(4), 803-835.

Sirgany, S. (2016). Egypt toughens punishment on female genital mutilation. CNN online ed., http://www.cnn.com/2016/12/08/middleeast/egypt-law-fgm/, accessed December 29, 2016.

Snow, R. C., Slanger, T. E., Okonofu, F. E., Oronsaye, F., \& Wacker, J. (2002). Female genital cutting in southern urban and peri-urban Nigeria: self-reported validity, social determinants and secular decline. Tropical Medicine and International Health, 7(1), 91100.

UNFPA-UNICEF. (2013). Joint evaluation, UNFPA-UNICEF Joint Programme on Female Genital Mutilation/Cutting: accelerating change, 2008-2012. Country Case Study: Senegal. Executive Summary.

UNICEF. (1998). The progress of nations. New York: United Nations Children's Fund.

UNICEF. (2013). Female genital mutilation/cutting: a statistical overview and exploration of the dynamics of change. New York: UNICEF.

UNICEF. (2016). Female genital mutilation/cutting: a global concern. New York: UNICEF.

Valderrama, J. (2002). Female genital mutilation: Why are we so radical? The Lancet, February $9,2002,539,359$.

WHO. (1999). Female genital mutilation: programmes to date: what works and what doesn't. A review (WHO/CHS/WMH/99.5). Geneva: World Health Organization

WHO. (2006). Female genital mutilation and obstetric outcome: WHO collaborative prospective study in six African countries. Lancet, 367, 1835-1841.

WHO. (2008). Eliminating female genital mutilation: an interagency statement. (WHO, UNFPA, UNICEF, UNIFEM, UNHCHR, UNHCR, UNECA, UNESCO, UNDP, UNAIDS). Geneva: World Health Organization

WHO. (2010). Global strategy to stop health-care providers from performing female genital mutilation. Geneva: World Health Organization

Yoder, P. S., \& Wang, S. (2013). Female genital cutting: the interpretation of recent DHS data. Calverton, Maryland: ICF International. 